\title{
Master Plan Preparation for Arakkonam Town using Remote Sensing and GIS
}

\author{
Shyam Sundar Raj R., Murugasan R., Venkatesan C. \\ Institute of Remote Sensing, Anna University, Chennai-600025, India \\ E-mail:murugasanr@rediffmail.com
}

\begin{abstract}
The main objective of this paper is to prepare a master plan for Arakkonam town in India. The study illustrates the use of Geographic Information System (GIS) and Multicriteria evaluation (MCE) technique for the selection of suitable sites in the study area for urban development. Google Earth and Toposheet were used to generate various thematic layers using ArcGIS software. Soil, geology, geomorphology, groundwater, rail network, road network and land use/land cover layers were integrated and weighted overlay analysis was performed to arrive at the final site suitability map. The master plan was prepared by projecting the population for next 20 years by Geometric Growth Method for the study area and planning zones such as Residential, Commercial, Industrial, Educational and Recreational were delineated as per Urban and Regional Development Plans Formulation and Implementation (URDPFI) guidelines.
\end{abstract}

Keywords: Master plan; Thematic layers; Urban suitability; Planning zone.

\section{Introduction}

Master plan is prepared for town and cities giving emphasize for zoning regulation for judicious use of urban land. Master Plan is a key development plan to provide land use allotment for residential, commercial, industrial, public and semi-public, traffic and transportation, parks, play fields and open spaces, etc., taking into consideration the existing land uses. The plans while suggesting for broader land use restrictions, will also identify the problem areas in traffic and transport, location for education, recreation site etc., and propose for provision of infrastructure facilities based on the projected population for those areas. Master plan is the blue print for the future and it is a comprehensive document, long-range in its view, intended to guide development in township for next 10 to 20 years. In this paper, an attempt was made to prepare master plan for Arakkonam town in Tamilnadu state in India.

\section{Objectives of the study}

The main objective of this study is to prepare a Master Plan for Arakkonam town in Tamilnadu state in India and it has the following sub-objectives,

1) To prepare various thematic layers such as soil, geology, geomorphology, groundwater and transportation network for the study area.

2) To carry out urban suitability analysis by considering the above thematic layers.

3) To classify the study area into various planning zones and proposing a Master Plan for the study area.

\section{Scope of the work}

The scope of the present work is as given below.

1) Water body and forest are preserved and airport is protected.

2) Residential, commercial, industrial, educational, hospital and recreational zones are classified as per Urban and Regional Development Plans Formulation and Implementation (URDPFI) Guidelines in India.

3) Population is projected for 20 years by geometric growth Method and master plan is prepared for next 20 years.

\section{Literature survey}

The exploitation of remote sensing and geographic data are used to study the metropolitan expansion, land use patterns and land cover classification. Combination of satellite imagery in multi-spectral mode can be efficiently

** Received 20 June 2018 ** 
exploited for studying metropolitan growth in detail [1]. Object oriented techniques of segmentation is one of the important elements in producing a detailed landuse classes of the urban planning mapping [2]. Thematic layers such as soil, geology, geomorphology, drainage, groundwater, elevation and transportation network were used to prepare master plan [3]. Toposheets, High resolution satellite imagery and Google Earth data were used to prepare thematic layers [4-9]. Thematic layers were overlaid by Analytical Hierarchical Process (AHP) and provided weightages for each layer to produce suitability map for urban planning [3-5, 9]. Landuse zoning plan and administrative map can also be used for urban planning [9]. GIS based multicriteria evaluation technique is very simple and flexible which could be used for preparing site suitability map [3, 5, 10].

The conclusions arrived from literature surveys are,

1) The literature review provides sufficient information about planning by using remote sensing satellite imagery.

2) Mostly ERDAS Imagine and ArcGIS software are used to classify and generate the maps for town planning.

3) The parameters considered in the existing literature for town planning studies are soil type, drainage condition, rail, road, geology and geomorphology.

\section{Methodology}

The steps involved in this study are briefly outlined as follows.

1) Preparation of thematic layers for the Soil, Groundwater, Geology and Geomorphology features in the study area.

2) Extraction of the Rail network and Road network features from Google earth.

3) Preparation of LULC for Arakkonam Town.

4) Integrating layers in GIS.

5) Assigning weightages for layers.

6) Evolving criteria for land suitability for various uses.

7) Preparation of land suitability map for study area.

8) Projection of population estimation for Arakkonam town.

9) Delineation of planning zones by using URDPFI guidelines [11].

10) Preparation of Master Plan for Arakkonam town.

\subsection{Study area}

Arakkonam is a municipality in Tamilnadu state in India, with a population of about 101,626 as per the census 2011. The area of this town is 100.140 Sq.km bounded by coordinates $13004^{\prime} 40^{\prime \prime} \mathrm{N}$ and $79044^{\prime} 00^{\prime \prime} \mathrm{E}$. The keyhole map of study area is shown in Figure 1.

\subsection{Data used}

The data used for the preparation of a master plan for the study area are listed as follows,

1) Toposheet (57-O/12) from Geological Survey of India

2) Soil map and Geology map from Geological Survey of India, Geomorphology map and Groundwater map from Bhuvan.

3) Transportation network from Google Earth.

4) Population data from Census of India (1991, 2001, 2011) [12].

\section{Preparation of thematic layers}

Soil, geology, geomorphology and groundwater layers were obtained from Institute of Remote Sensing, Anna University, chennai. Transportation network and LULC were prepared by extracting the features from Google earth.Figure 2a represents soil map of study area. Three type of soil texture were found in the study area- clayey skeletel, coarse loamy and fine. Waterbody and habitation were masked in this map due to non-availability of data. Figure $2 \mathrm{~b}$ represents geology map for Arakkonam planning area. In the study area, there are charnocknite, gneiss, granite and gneiss complex, sandstone and conglomerate and sandstone with shale/ coal partings were found.Figure 2c represents geomorphology map for Arakkonam planning area. In the study area, there are pediplain origin; plain and valley plain were found. Waterbodies are masked in this map due to non-availability of data. Plain region has covered most of the study area. Figure 2d represents groundwater map for the study area. In the study area, moderate potential zone covered and waterbodies are masked. Rail network for Arakkonam town was extracted from google earth imagery, which is represented in the Figure 2e. Road network for the Arakkonam town was extracted from the Google Earth imagery, which is represented in the Figure $2 \mathrm{f}$ and 
the roads were categorized into three components- Main Road, State Highway and Village Road. It was seen that there were three State Highways through the area- SH58, SH61 and SH126 while the village roads were connected to state highways through Main Road. LULC was prepared by extracting the features from Google Earth in KML format. Extracted features include settlement, vegetation, forest, barren land, water bodies and airport, which were converted into raster format in ArcGIS software by using conversion tools as shown in Figure 2g.

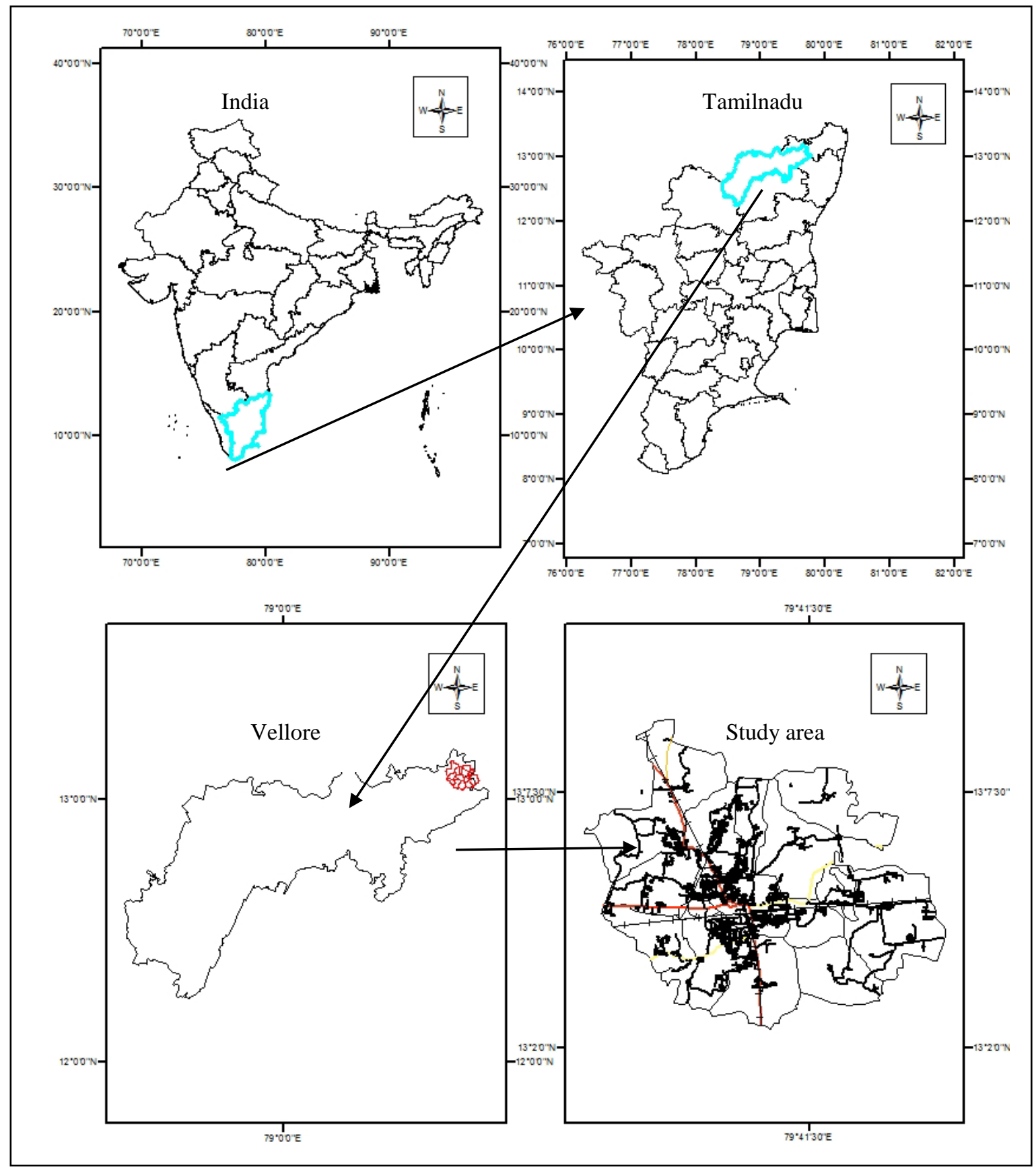

Fig. 1. Keyhole map of Arakkonam town 


\section{Urban land suitability analysis}

Land suitability analysis was carried out by overlaying the soil, geology, geomorphology, groundwater, landuse/landcover, rail network and road network layers and providing weightage to each layer as discussed below.

\subsection{Weighted overlay}

Weightage was provided to each layer and weighted overlay was performed by integrating all layers. Finally, three suitability maps were generated for residential, commercial and industrial suitability map by giving different weightages as given in Table 1, wherein the ranking depicting as follows: 4 - highly suitable, 3 moderately suitable, 2 - less suitable and 1 - not suitable. Each map had four categories of interest- highly suitable, moderately suitable, less suitable and not suitable.

\subsection{Residential suitability map}

The residential suitability map was prepared by overlaying the thematic layers and providing weightage for each layer with emphasis on residential suitability parameters and components. In the study area, it was found that highly suitable area covered 51.07 sq. km, moderately suitable covered 13.24 sq. $\mathrm{km}$, less suitable covered 2.321 sq.km and not suitable covered 33.87 sq.km. Residential suitable map was shown in Figure 3a.

\subsection{Commercial suitability map}

The commercial suitability map was prepared by overlaying the thematic layer and providing weightage for each layer by taking into commercial aspects into consideration using weight allocation. In the Suitability map, the highly suitable area covered $36.899 \mathrm{sq} \mathrm{km}$, moderately suitable area covered $22.705 \mathrm{sq} . \mathrm{km}$, less suitable covered $1.820 \mathrm{sq} \mathrm{km}$ and not suitable covered 39.092 sq.km. Commercial suitability map is shown in Figure $3 \mathrm{~b}$.

\subsection{Industrial suitability map}

The industrial suitability map was prepared by overlaying the thematic layers and providing weightage for each layer based on the industrial factors and their appealing conditions. It was found that highly suitable comprised of 6.652 sq.km, moderately suitable, 13.678 sq km, less suitable, 46.0926 sq km and not suitable, 33.402 sq km. The Industrial suitability map for the study area is shown in Figure 3c.

\subsection{Master plan preparation}

Master plan was prepared for Arakkonam town, giving emphasize for zoning regulation for judicious use of urban land and development in township for next 20 years.

\subsection{Population projection and density}

Population projection, in the field of demography is an estimate of future population while Population density is a measurement of population per unit area. Population, which was projected by geometric growth method based as per 2011 census data was found to be 141429. Table 2 represents population projection and density for Arakkonam Town.

\subsection{Land use zoning}

Zoning is a technique, which is used for land-use planning and a primary tool for urban planning. To provide a land use allotment for Residential, Commercial, Educational, Industrial and Hospital zones, the planning was carried out by URDPFI guidelines. Table 3 represents Arakkonam planning area. Master Plan was proposed based on the stated guidelines and is shown in Figure 4. 


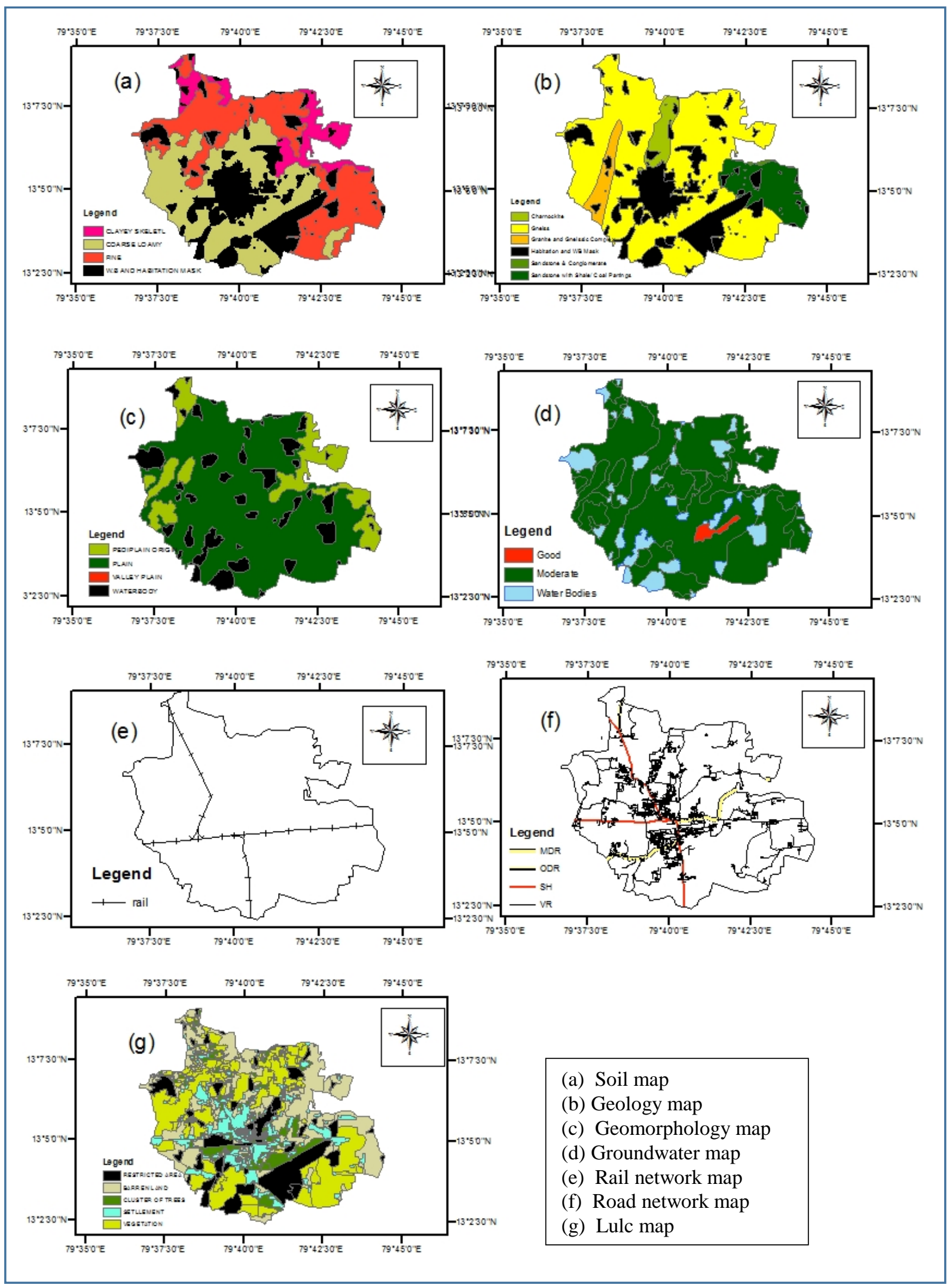

Fig. 2. Thematic layers in scale 1:10000 
Table 1 . Weightages for suitability analysis

\begin{tabular}{|c|c|c|c|c|c|c|c|}
\hline \multirow{2}{*}{ Criteria } & \multicolumn{3}{|c|}{ Weightages } & \multirow{2}{*}{ CONDITION } & \multicolumn{3}{|c|}{ Ranks } \\
\hline & Resi & Comm & Indus & & Resi & Comm & Indus \\
\hline \multirow{4}{*}{ Soil } & \multirow{4}{*}{20} & \multirow{4}{*}{15} & \multirow{4}{*}{15} & Coarse Loamy & 4 & 4 & 4 \\
\hline & & & & Fine & 3 & 3 & 3 \\
\hline & & & & Clayey Skeletl & 2 & 2 & 2 \\
\hline & & & & Waterbody and Habitation Mask & 1 & 1 & 1 \\
\hline \multirow{4}{*}{ Geology } & \multirow{4}{*}{5} & \multirow{4}{*}{5} & \multirow{4}{*}{5} & Gnesis & 4 & 4 & 4 \\
\hline & & & & Sandstone and Standstone with Shale & 3 & 3 & 3 \\
\hline & & & & Charnockite and Granite & 2 & 2 & 2 \\
\hline & & & & Waterbody and Habitation Mask & 1 & 1 & 1 \\
\hline \multirow{4}{*}{ Geomorphology } & \multirow{4}{*}{5} & \multirow{4}{*}{5} & \multirow{4}{*}{5} & Plain & 4 & 4 & 4 \\
\hline & & & & Pediplain & 3 & 3 & 3 \\
\hline & & & & Valley Plain & 2 & 2 & 2 \\
\hline & & & & Waterbody & 1 & 1 & 1 \\
\hline \multirow{2}{*}{ Groundwater } & \multirow{2}{*}{15} & \multirow{2}{*}{15} & \multirow{2}{*}{10} & Good and Moderate & 4 & 4 & 4 \\
\hline & & & & Waterbody & 1 & 1 & 1 \\
\hline \multirow{4}{*}{ LULC } & \multirow{4}{*}{30} & \multirow{4}{*}{25} & \multirow{4}{*}{25} & Barren Land & 4 & 4 & 4 \\
\hline & & & & Vegetation & 3 & 3 & 3 \\
\hline & & & & Cluster of Trees & 2 & 2 & 2 \\
\hline & & & & $\begin{array}{l}\text { Developed Area, Forest, Waterbody, } \\
\text { Airport }\end{array}$ & 1 & 1 & 1 \\
\hline \multirow{4}{*}{ Rail } & \multirow{4}{*}{10} & \multirow{4}{*}{18} & \multirow{4}{*}{15} & $<500 \mathrm{~m}$ & 4 & 4 & 1 \\
\hline & & & & $1000-500 \mathrm{~m}$ & 3 & 3 & 2 \\
\hline & & & & $1500-1000 \mathrm{~m}$ & 2 & 2 & 3 \\
\hline & & & & $>1500 \mathrm{~m}$ & 1 & 1 & 4 \\
\hline \multirow{4}{*}{ Road } & \multirow{4}{*}{15} & \multirow{4}{*}{17} & & $<500 \mathrm{~m}$ & 4 & 4 & 1 \\
\hline & & & & $1000-500 \mathrm{~m}$ & 3 & 3 & 2 \\
\hline & & & 25 & $1500-1000 \mathrm{~m}$ & 2 & 2 & 3 \\
\hline & & & & $>1500 \mathrm{~m}$ & 1 & 1 & 4 \\
\hline
\end{tabular}

Table 2. Population projection and density for Arakkonam town

\begin{tabular}{|c|c|c|}
\hline YEAR & POPULATION & DENSITY \\
\hline 1991 & 113986 & 11 \\
\hline 2001 & 128901 & 13 \\
\hline 2011 & 141429 & 14 \\
\hline 2018 & 153839 & 15 \\
\hline 2038 & 195497 & 20 \\
\hline
\end{tabular}

Table 3. Arakkonam planning area

\begin{tabular}{|c|c|c|}
\hline SECTOR & URDPFI GUIDELINES & PLANNING AREA(Ha) \\
\hline Residential & $45-50 \%$ & 4513.97 \\
\hline Commercial & $2-3 \%$ & 225.19 \\
\hline Industrial & $8-10 \%$ & 832.16 \\
\hline Educational & Based On Condition & 162.92 \\
\hline Hospital & Based On Condition & 68.34 \\
\hline Developed Area & - & 755.10 \\
\hline Recreational & $12-14 \%$ & 1470.08 \\
\hline Restricted Area & - & 2013.04 \\
\hline \multicolumn{2}{|c|}{ TOTAL } & $\mathbf{1 0 0 4 0 . 8}$ \\
\hline
\end{tabular}




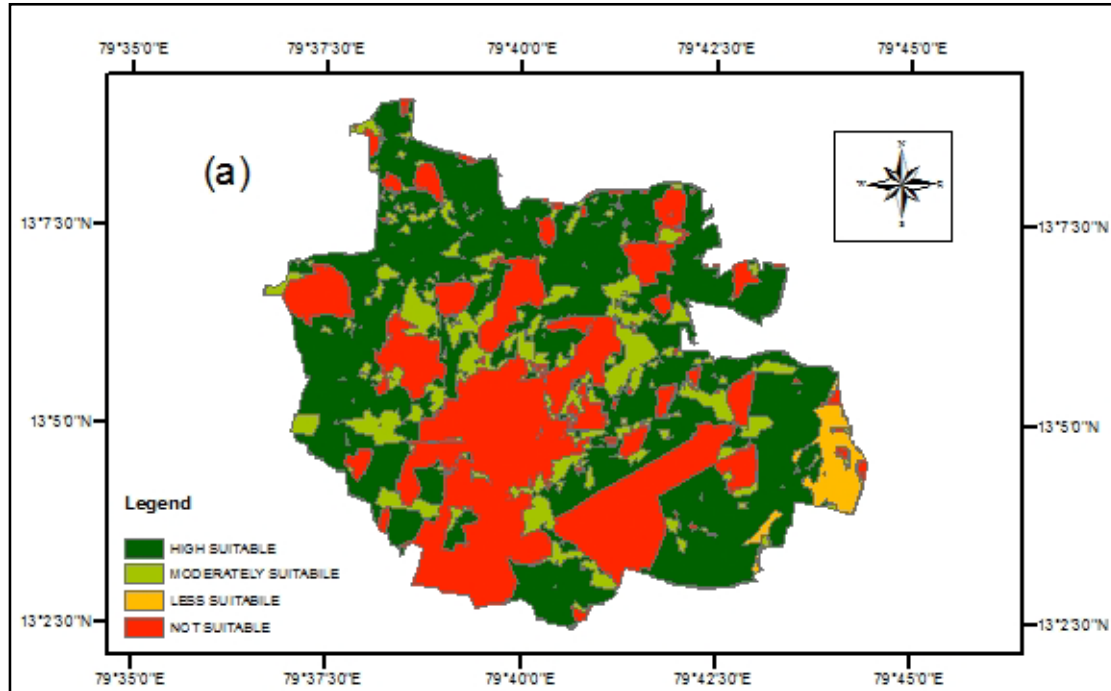

(a) Residential suitability map

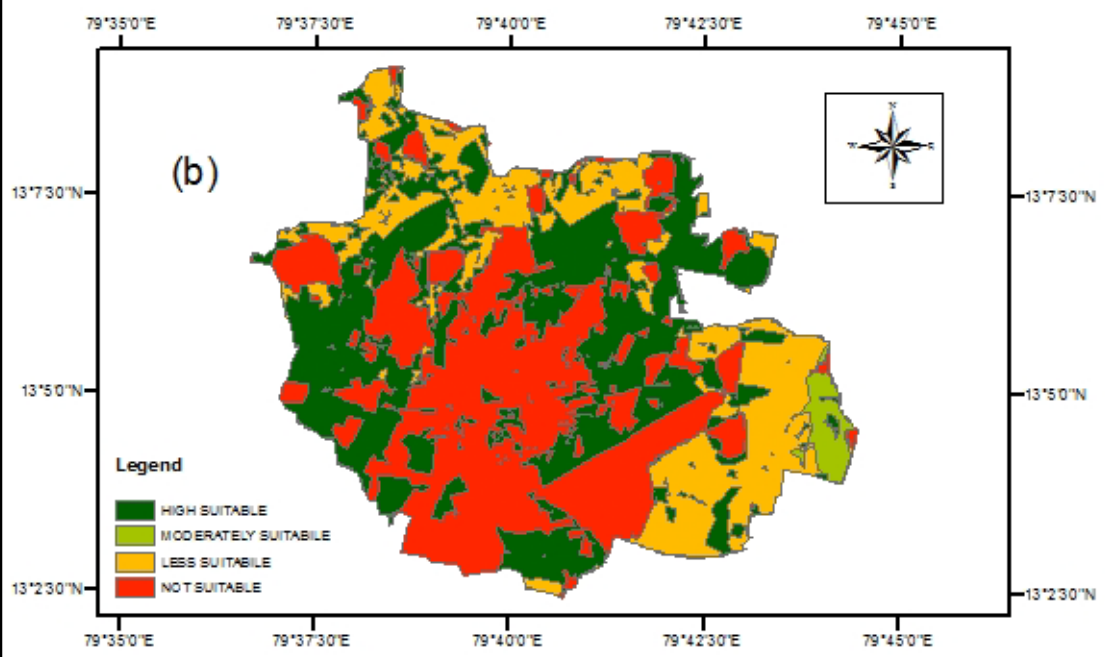

(b) Commercial suitability map

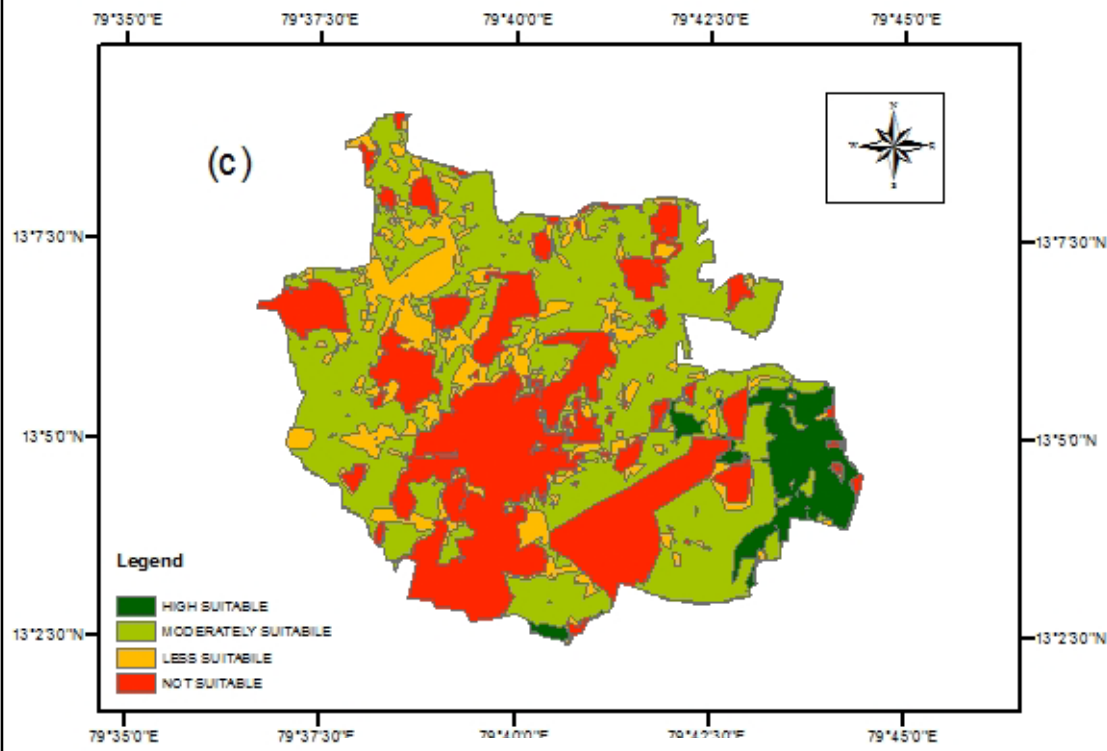

(c) Industrial suitability map

Fig. 3. Suitability map in scale 1:10000 


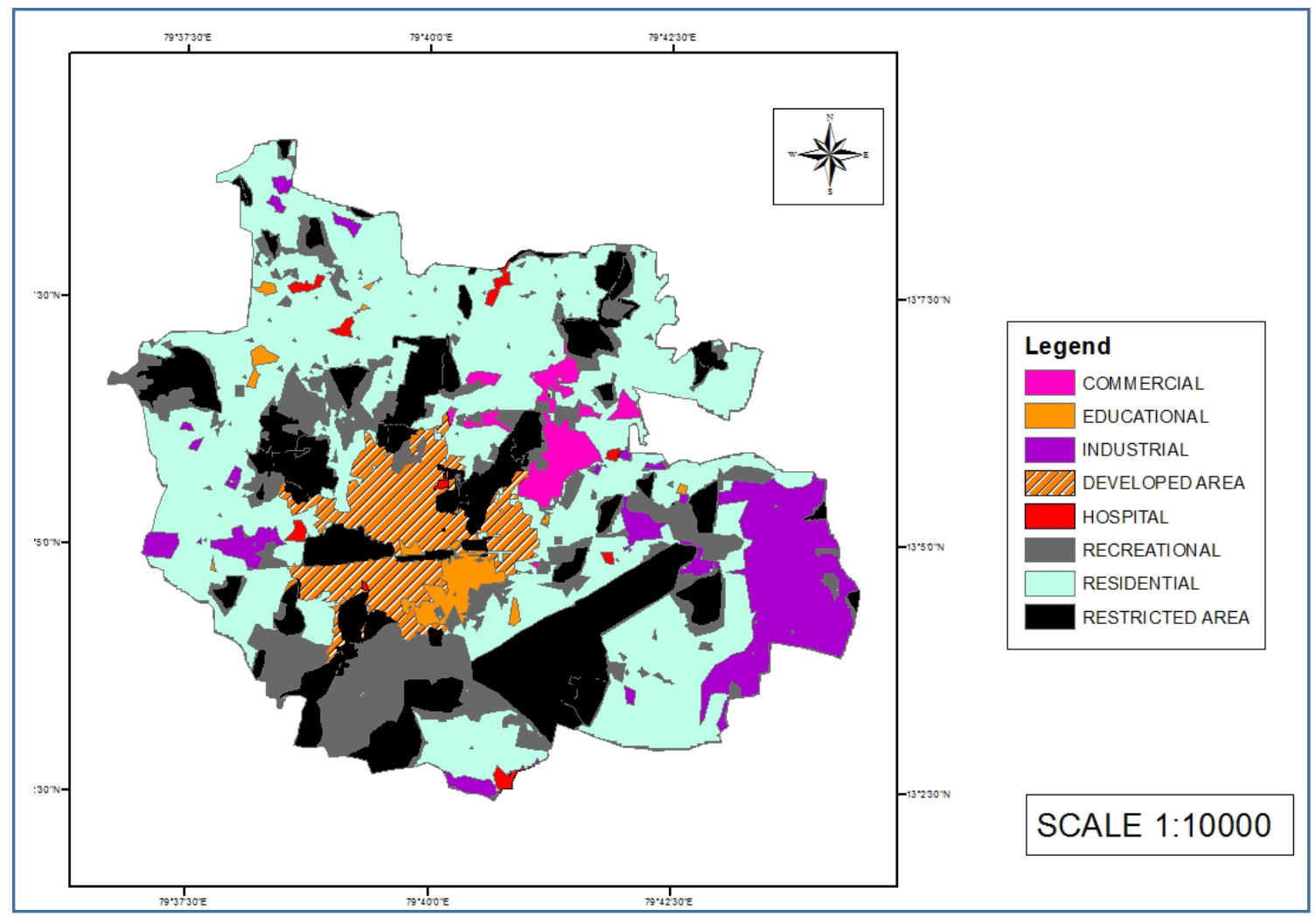

Fig. 4. Master plan for Arakkonam town planning area

\section{Conclusions}

Conventional method of master plan preparation involves field survey and preparation of drawings either manually or by drawing software. This study focused on the preparation of Master plan for Arakkonam Town using remote sensing and GIS techniques, overcoming the tedious and high time consumption problem in the conventional method. By the use of GIS software and remote sensing technique various thematic layers were generated, such as soil, geology, geomorphology, groundwater, landuse/landcover and transportation network. Land suitability map was prepared for residential, commercial and industrial purposes by overlaying the thematic layer and providing weightage to each layer. As per URDPFI guidelines various planning zones were delineatedresidential (4513.97 Ha), commercial (225.19 Ha), industrial (832.16 Ha), educational (162.92 Ha), hospital $(68.34 \mathrm{Ha})$ and recreational $(1470.08 \mathrm{Ha})$ and finally, the master plan for the study area was prepared by projecting the needs for the next 20 years.

\section{References}

[1] Mohsin J. B., Ahmad W and Muhammad Farooq Iqbal. Assessment of urban sprawl of Islamabad metropolitan area using multi-sensor and multi-temporal satellite data. Arabian Journal for Science and Engineering, 2012, 37: 101-114.

[2] Norzailawati Md Noor and Alias Abdullah. Sustainable urban Planning mapping using remote sensing and GIS in Malaysia. Conference on Joint urban remote sensing event, Swirtzerland, 2015: 1-5.

[3] Sujit P. and Deepak R. Implementing GIS and RS for city planning and management. International Journal of Advanced Research in Computer Engineering and Technology, 2015, 4: 1961-1966.

[4] Geogrred B., Kallopi G. P. and Dimitrious P. Potential suitability for urban planning and industry development using natural hazard maps and geological-geomorphological parameters. Environmental Earth Sciences, 2012, 66: 537-54.

[5] Manish kumar and Vasim Riyasat Shaikh. Site suitability analysis for urban development using GIS based multicriteria evaluation techniques. Journal of the Indian society of Remote sensing, 2012, 41: 417-424. 
[6] Sandipan Das, Aniruban Bhattacharya and Sagarmali. Study on urban land suitability assessment using remote sensing and GIS: a case study of Khairagarh. International Journal of Computer Application, 2013, 74: 20-26.

[7] Devendra Pandey. Land Use Land Cover planning of Gondia Municipal city, Maharashtra state, India Using RS and GIS. International Journal of Life Sciences Biotechnology Pharma Research, 2012, 1(1): 4664.

[8] Akanbi A K, Santosh Kumar and Uwaya Fidelis. Application of RS, GIS and GPS for efficient urban management plan. Novus International Journal of Engineering and Technology, 2013, 2(1): 1-14.

[9] Fasona M. J. and Omojola A. S. GIS and remote sensing for urban planning: a case of Festac town, Lagos, Nigeria. International Conference on Geomatics, 2004:451-458.

[10] Ariyalur Master Plan Report prepared by Institute of Remote Sensing, Anna University, Chennai. 2004.

[11] URDPFI guidelines. Ministry of Urban Development, 2014, Website: http://mohua.gov.in/link/urdpfiguidelines.php

[12] Census of India. 1991, 2001, 2011, Website: http://censusindia.gov.in 